\title{
Re-understanding Deification and Hunger: An Ecocritical Venture into Shiva Purana
}

Patrika Handique ${ }^{1}$ and Anurag Bhattacharyya*2

${ }^{7}$ Research Scholar, Department of English, Dibrugarh University, Dibrugarh, Assam, India

${ }^{2}$ Assistant Professor, Department of English, Dibrugarh University, Dibrugarh, Assam, India

Corresponding Author: Anurag Bhattacharyya, E-mail: anuragdu2009@gmail.com

\section{ARTICLE INFORMATION}

Received: December 47, 2020

Accepted: January 14, 2021

Volume: 3

Issue: 1

DOI: $10.32996 /$ jhsss.2021.3.1.12

\section{KEYWORDS}

Mythology, Religion, Ecocriticism, Deification, Hunger,

Environmentalism, Enlightenment

\section{ABSTRACT}

The advent of the Eighteenth Century witnessed emergence of a scientific temperament and shook the foundation of faith or religion in an unbelievable manner. Industrial Revolution, World Wars aggravated the situation and a conflict between science and religion has been prevalent since then. People began to neglect the mores and preaching of theological philosophy and even the tradition and customs handed down by religion or otherwise also culture. In the era of overall degradation, it has become the need of the hour to restore theology, spiritual and mythical works for re-learning the meanings of humanity and wisdom, although the elimination of religious blindness needs to be done. It is discerned that people discard the ancient philosophy and myths to be irrational and nonscientific, but it is not true. Religion, ancient philosophy and conduct of life is intertwined intricately. In religion and culture, myths and folklores remain popular and are handed down from generation to generation and appear to be so fictional. But, in reality, they carry innumerable valuable messages and codes for life. So, this study intends to shed the irrationality and illuminate the rational and significant implications in the text Shiva Purana, which forms a part of the very precious Mahapuranas, spiritual and mythological text of Hindus. The paper would, however, attempt an ecocritical study of the specified text. As ecological concerns have called for urgent attention, ancient wisdom can assist scientific ideologies and thus, go hand in hand to unite humans to become environmentally sensitive.

\section{Introduction}

The term "Ecocriticism", for the first time, appeared in the essay of William Rueckert "Literature and Ecology: An Experiment in Ecocriticism" in the year 1978. In 1989, a Western Literature Association Meeting was organized, where Cheryll Glotfelty proposed for the usage of the term in the critical arena of nature writing studies. This conference facilitated the term to thrive and flourish. After that, two remarkable works The Ecocriticism Reader, edited by Cheryll Glotfelty and Harold Fromm and The Environmental Imagination: Thoreau, Nature Writing, and the Formation of American Culture by Lawrence Buell officially acclaimed the genre and critical theory. Glotfelty examines in the introductory note of The Ecocriticism Reader: "Ecocriticism is the study of the relationship between literature and the physical environment.... Ecocriticism takes an earth-centered approach to literary studies" (Glotfelty, 1996, p. xviii). The genre of nature writing has got different names like ecopoetics, environmental humanities, green studies, green cultural studies, environmental literary criticism and so on. Ecocriticism, as a branch of critical study, believes in the mutual relationship between humans and non-humans, both affecting each other tremendously. Ecocritics, hence, analyze the relationship between literature and environment. They explore the portrayal of nature, environmental consciousness, ethics etc. in literary works. The theory, basically, supports a bio-centric relationship between all the components of nature.

Now, Mythology is one of the diverse genres of literature which analyzes folk tales, divine stories, and collection of sacred stories of a culture, commonly known as myths. Mythology or myths, generally, attempts to project human condition and the contemporary concepts or ideologies through supernatural and common characters. They deal with the ideas of good and evil, truth, justice, origin of creations and also put forward deeper insights regarding meanings of life and death, suffering, moral

K C AL-KINDI CENTER R D FOR RESEARCH AN Your gateway to world-class research

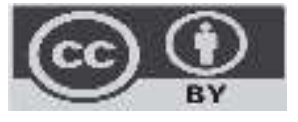

Published by Al-Kindi Center for Research and Development. Copyright (c) the author(s). This open access article is distributed under a Creative Commons Attribution (CC-BY) 4.0 license 
culture and much more. Joshua J. Mark describes in his article "Mythology": "A myth is a story, presented as having actually occurred in a previous age, explaining the cosmological and supernatural traditions of a people, their gods, heroes, cultural traits, religious beliefs, etc. The purpose of myth is to explain, and, as Sir G.L. Gomme said, myths explain matters in the science of a pre-scientific age". Myths or Mythologies are integral part of religion and if they are parted, they may not carry the same meaning to the people of that religion. Moreover, these myths become a part and parcel of their culture as they are handed down from generation to generation. Nations and religions, across the world, have varied myths and folklores pertaining to their respective cultures.

India, too, is rich with myths and mythological works. The Hindu Puranas contain many anonymous texts like the Mahapurana, 17 Mukhya Puranas or Major Puranas and 18 Upa Puranas or Minor Puranas and all of them narrate myths and legends. Originally written in Sanskrit language, these texts are generally credited to the author, Veda Vyasa and are believed to have been composed over the years spanning from $350 \mathrm{CE}$ to $1500 \mathrm{CE}$. Now, the text which is designated as Mahapuranas is a compilation of eighteen Puranas. Among them, the Mythological classic, Shiva Purana, the selected text for the study, consists of episodic tales that not only eulogizes the life of Lord Shiva but also puts forward reasons for it. The deities that are described emit positive values and the portrayal of their deeds and ideologies impart moral ethics. Apart from inculcating spirituality, this mythical work is also illuminated with wisdom. Victorian and Modern Age witnessed a lot of advancements in Science and technology, thus crumbling the ancient foundation of innocence, religious faith and spiritual shroud all over the world. But, the decline in the quality of life in the contemporary period is gradually compelling the commoners and the intelligentsia to search for better refuge, whether it be the upliftment of the morality or purity in everything. In this process of research and enquiry for well-being of humans, thinking tanks can consider the revival of ancient mythological and religious texts to preach righteousness of thoughts and actions.

Now, environmental degradation has become a fundamental problem and a big task to tackle. Environment should no longer be only a subject matter to study but it has become tremendously important to raise environmental consciousness among the mass. Here, scientific theories and spiritually replete texts can go hand in hand towards a resolution. It is a well-known fact that literature not only provides delight but also instructs. So, Mythical literature and Spiritual scriptures of different religions can become a beneficial medium to arouse ecological awareness and teach eco-ethics. Nowadays, religion and ecology are also emerging as interesting fields for research scholars. These scholars are trying to trace environmental awareness in the different philosophical traditions like Buddhism, Jainism, Hinduism, Daoism, Christianity, Islam etc. Mythical and Spiritually embedded works like Ramayana, Mahabharata, The Puranas, The Bhagavad Gita, The Vedas etc. of India are examples too, which contain elevated truths and wise lessons along with an eco-sensitive philosophy. Among all the aforementioned mythical representations, Shiva Purana has been specifically selected for a detailed analysis from an Ecocritical angle. This research paper intends to analyze environmentalism of this work.

\section{Objectives of the Study}

The text which has been specifically selected for a detailed analysis is the part Shiva Purana from the voluminous text All 18 Major Puranas translated by International Gita Society. The study has the objective to examine the environmental ethics that have been communicated in Shiva Purana and to delve deep into the inner implications of diverse illustrations and stories. It intends to examine the rational ideas behind the mythical fables, which is otherwise misjudged as illogical and mere fantasy.

\section{Methodology}

The method of Content Analysis of both Primary and Secondary Sources will be applied in the study. The tools of Western views of Ecocriticism and Deep Ecology in addition to Indian Theology will be applied for a deep analysis of the selected works.

\section{Discussion}

Reading of the mythical texts would bring the realization that these works are abundant with symbolical references. The composition, Shiva Purana is no exception and many deities, their audacious acts, their valuable principles, humans, their follies, demons and their evil doings are included. But, it is to be observed that the manner of description and illustrations have the purpose of instructing values, after all. Noticeably, deification and many other expositions have layers of symbolical interpretation, with which this introspective reading has tried to deal with.

Shiva Purana apparently portrays Lord Shiva, his entire family and his habitats. A sincere peek into their illustrations will unearth the rich biological diversity that the family and their abodes display. The family of Lord Shiva is embellished by all components of nature. Nature, itself, has been deified in the form of Parvati, the consort of Lord Shiva. Himalaya, the mountain, is the father-inlaw while Ganga, the mighty river is the sister-in-law of the Lord. Different elements and species from the natural kingdom are dear to Lord Shiva. The Supreme Lord has two adorable sons- Ganesha and Kartikeya. Ganesha with the head of an elephant symbolizes the possibility of the harmonious co-existence of human and animal world. Again, the Gods and Goddesses have 
their respective mounts which are portrayed to be the strength of the deities. They are not projected to be exploited or dominated by the deities. Shiva's bull mount, Nandi, belongs to the animal kingdom. The serpent around his neck represents the reptilian species. The lion-mount of Goddess Parvati indicates wildlife. The vehicle of Kartikeya, peacock, is included in avian species while the mouse that is the vehicle of Ganesha implies small underground animals. Thus, animals from different communities are inhabitants at the holy home of Shiva and Parvati. Interesting is the sight of a joyous co-existence of all the animals, despite being natural enemies. The carnivorous lion's food is the vegetarian bull, the peacock is the enemy of the serpent and the mouse is the serpent's food; nevertheless, all live together. The scenario and the sacred abode, Kailas depicts an existence where everyone has overcome their hunger. Again, in the text, Lord Vishnu is portrayed to have his rest-place in the lap of a gigantic serpent. Records say that Vishnu rests on "Shesh-Nag and being attended by Garuda and other attendants", which symbolically presents inter-dependence between the Supernatural and his creations (Shiva Purana). Nowhere, in the text, can one find domination. It is only growing clearer that the animals and other creations extend a helping hand to the Supreme in the smooth and peaceful functioning of the Universe. It can be understood that the manner of deification and all other detailing have allusive meanings to preach eco-sensitivity. Moreover, description shows that Lord Shiva gulped down poison to protect the Environment against its harmful effects, thereafter receiving a blue throat gaining the name 'Neelkanth'. The legend narrates that ocean was being churned to produce nectar, the dose for immortality. But the process also released poison as a bi-product. It can be analyzed that water resources are believed to be resource of nectar according to the Vedic wisdom. It is so because water sustains life and it possesses medicinal properties too: "Amrita is in the waters....the waters hold all medicines" (Krishna, 2017, p. 73). This legend also explicates that over-exploitation of resources for selfish interests will only invite destructive and toxic factors like the poison. Here, the Neelkanth emerges as an environmentalist and this deity urges everyone to become aware towards the environmental protection. The descriptions of the deities convey underlying meanings of the interdependent and harmonious relationship of all elements for the existence of the Earth. Anand Singh remarks in his work Planet, Plants \& Animals: Ecological Paradigms in Buddhism:

Environmental ethics needs a significant departure which can signify an all-pervasive system including both biotic and abiotic species. It implies an interrelationship of all these species and their environment which will sustain the human existence through balance of ecosystem by conserving and preserving natural resources (Singh, 2019, p. 6).

Again, Kartikeya instructs Sage Vamadev regarding the last rites of a Sanyasi that 'prasada' should be offered to a girl or a cow. Thus, the expressions and wise words of the deities advocate environmental sensitivity. Feeding animals is delineated to be holy deeds and thus, appreciated. It is being told that such compassionate acts bring virtues to a person. Ganesha, too, disguised himself as a cow to condemn inconsiderate treatment upon animals. In the Shiva Purana, a story is being recounted that a sage named Gautam was falsely plotted into a fake sin by other hermits. So, Ganesha beguiled as a cow and started grazing at Gautam's farm. Gautam, in attempt to scare the animal out, hit her back with a blade of grass. Acting according to the conspiracy, Lord Ganesha pretended to die in an instant. But, this incident affected Sage Gautam immensely and he was full of remorse. Lord Shiva, finally helped in his liberation. Now, this story preaches that cruelty and brutality over other lives is considered to be a sin by ancient wisdom. Though the incident was fake, still the moral is significant. It shows that ancient tradition never supported unjustified killing or any kind of insensitive conduct towards animals.

It has already been mentioned in the previous paragraph that Parvati is the deification of Nature. In the classic, her expression towards Shiva is penned down: "I am 'Prakriti' (Nature) and you are the 'Purusha' (almighty).You exist in the 'Sagun' form (with form) because of me. In my absence, you will find it impossible even to exist (Shiva Purana). Such an assertion indicates the significant role played by nature in the existence of all creations. Infact, Buddhist text and traditions reflect such an eco-centric perspective too. In the text, Planet, Plants \& Animals: Ecological Paradigms in Buddhism, the author believes "Nature to be an entity from which everything has originated and from which human beings cannot be alienated. Nature is not a mere physical world external to man" (Singh, 2019, p. 14). Indian Philosophical traditions opine that all created organisms and non-living matter are nothing but manifestation of the Almighty spirit. It is Nature that supports their identity and existence, if at all. So, regard for nature and interdependence in it is necessary for the continuation of life.

Shiva Purana also mentions about the famous eight idols dedicated to the different incarnations of Lord Shiva. They are namely Sharva, Bhava, Rudra, Ugra, Bhima, Pashupati, Ishan and Mahadeva. It is described that the named idols are associated with the eight essential natural elements which are land, water, fire, air, sky, soul, Sun and the Moon. In this way, these elements have already been made sacred with their deification. There is a scientific reasoning behind such deification. The equilibrium between these elements is essential for environmental sustenance. In the book Pancamahabhutas, the author, Imti Samuel Longkumer puts forward that "Depletion and destruction of the environment is all but because of disrespect, disregard to the simple but vital elements" (Longkumer, 2009, p. 289). Shiva Purana includes descriptions of different customary rituals of religious devotion. A rite directs reverential worship of Parthiva linga and the eight idols mentioned earlier. Thus, it can be apparently observed that these primal constituents of the cosmos are being deified and regarded in the Indian belief system. It appears that deification is an ancient methodology of the rational and scientific processes to the ignorant and innocent dwellers. The infusion of reverential 
attitude towards nature makes these people representatives of environmental preservation. The specific text, Shiva Purana also records sacred rituals of worshipping varied deities such as Sun God, Moon God, Varuna, Nandi etc. while engaging in "mental worship of Shiva" (Shiva Purana). It clarifies that the Indian philosophical system believes in the importance of the influential elements, animals and natural objects and therefore, are being deified in ancient literature. Nanditha Krishna in the "Introduction" of her work, Hinduism and Nature, records "Vedic religion was pantheistic, celebrating nature as divinity" (Krishna, 2017, p. 3).

Besides all such deification, Ganga also appears as a deity but it must be reminded that she personifies the mighty holy river. She is delineated to be the eldest daughter of Mountain Himalaya. Such descriptions imply the geographical fact that Ganga flows down from the Himalayas. In the classic, Shiva Purana, it is also narrated that she cascades down gently from Shiva's locks of hair. Legends glorify that water liberates trapped spirits of Earth who failed to secure salvation. The story of Prince Bhagirath's ancestors is an exemplification of such legendary myths. From these stories, it can be examined that father and daughters represent the non-human nature, namely mountains, rivers and broader perspective of nature. Through the projection of this lineage, the Vedic wisdom, exquisitely, conveys the idea of interconnection in the wholeness of the cosmos. These stories also advocate the importance of water for the existence of life. Therefore, water is deified, compared to nectar and idealized as a source of salvation.

"Pancamahabhutas" is an umbrella term which includes the elements- air, water, fire, earth and space and any disturbance in their constituency will destroy the ecosystem. Accounts of Shiva Purana reveal that all the five elements, known as Pancamahabhutas, erupted from Lord Vishnu's body. It carries the signification that these elements are therefore sacred and must be regarded. It also implies the interdependence between all the five elements and sacredness has been attached to them because of their prime role in the Universe. Thus, the deity, Lord Vishnu, represents the close link between the five elements and creation as well as sustenance of life.

Different Incarnations of the holy deities reflect that they resurrect to safeguard the planetary system from anti-ecological agents. The concept of rebirth is a recurrent theme which also points towards the theory of evolution. Not only this, this concept also wishes to make people turn compassionate towards other lives as well. Moreover, Pankaj Sharma, in his research book, Ecocriticism and the Ramayana of Tulsidasa expresses that "Myths of Vishnu's incarnations further sustain the ecological appeal of Indian mythology for they support the process of evolution of species" (Sharma, 2011, p. 14). A description that appears in the text propounds that Brahma, once transformed into a swan and Vishnu into a swan to compete with each other. Finally, the story teaches that all creatures including the deities were on a par. Such incarnations also makes it evident that everything is an expression of the Divine.

Further on, the classic, Shiva Purana registers that all the deities are also inter-connected and inalienable. The cascade of streams that flow out of Shiva's body is the dwelling place of Vishnu. The lotus flower that protruded out of Vishnu's navel was Brahma's habitat. Again, the trio collectively produced the golden egg that created the Earth and Heaven. In addition to these, it is jotted down that "Uma, was in fact mother Nature" and Saraswati as well as Lakshmi manifested from it (Shiva Purana). Such a picture of the deities apparently shows that everything including water sources, flowers etc. are sacrosanct in nature and originate from the divine. It presents that inter-connectivity and mutual dependence in Nature should be maintained to sustain the ecological balance.

Vedic Philosophy had always attempted to be instructive and take humans towards the right path of Dharma. Here, Dharma signifies righteousness of thoughts and actions. Although mythological literature is believed to be full of myths, yet one should remember that it is didactic in nature and there is logic and rationality behind the innumerable symbolical references. In the selected mythical text, a story is narrated that Narada, at one time, desired to get bethroated to the daughter of King Sheelnidhi. For this, he requested Lord Vishnu to bless him with handsome features. But, his face was replaced by a monkey's face. This story conveys that everything is beautiful and everyone should be contended with whatever one is bestowed with. One should have hunger for knowledge and well-being but never for transitory or materialistic gains.

The specific text has another tale which condemns hunger that is insensitive, anthropogenic and abusive. A goat reserved for sacrifice went missing, due to which, the care-taker, Narada became worried. He pleaded Kartikeya to find his he-goat. Narada added that he desperately wanted it for the accomplishment of a vow. Later, Kartikeya advises Narada that his yagya was already complete as it got blessings from the deity, Kartikeya himself. It is narrated as following: "Narada arrived and demanded his goat. I told him that his Yagya had been accomplished by my blessings and there was no need to sacrifice the poor goat. Narada-the Brahmin went back satisfied" (Shiva Purana). This story supports animal welfarism and cultivation of compassionate attitude towards non-human lives. So, Vedic literature too posits challenge against such culture of sacrifice in devotion. In the true essence, welfare of all is the motto of Dharma. Nanditha Krishna quotes from Mahabharata in her text, Hinduism and Nature: 
"Dharma is meant for all the well being of all living creatures. Hence that by which the welfare of all living creatures is sustained, that for sure is dharma" (Krishna, 2017, p. 2).

Ganesha is a deity with the head of an Elephant. The legend goes as such that Parvati ordered Ganesha to guard during her activity of taking a bath. Ganesha denied the entry of Shiva himself. Furious Shiva asked his ganas to engage in a battle against Ganesha. Witnessing the defeat of the ganas, Shiva took his turn to join the duel with Ganesha. Shiva could not bear his decreasing chances of victory and hence severed the head of Ganesha. This act of Shiva enraged Parvati and she demanded the return of her son's life. Helpless Shiva requested the deities to fetch the head of the first creature they meet and in this way, an elephant's head was enjoined to Ganesha's body. Now, Ganesha becomes a symbol of the cordial relationship between humans and animals. Infact, Narsimha is another deity who represents an amalgamation of lion and man and appeared to protect the Earth against the destroyer, Hiranyakshipu: "Lord Vishnu appeared in his incarnation of Narsimha (half lion and half man) and killed Hiranyakshipu with his sharp nails, during the dusk" (Shiva Purana). It indicates the essentiality of a harmonious existence for the ecological management. Again, Lord Vishnu took one more incarnation of a boar to annihilate Hiranyaksha, another demon, who threatened the smooth functioning of the Earth's system. Lord Shiva incarnated as Ox to slay down the cruel and brutal sons of Vishnu in the netherworld. Thus, timely incarnations as animals and blended souls point out that animals too have their individual purpose to serve in the continuation of life process. Deep ecology maintains that all human and non-human entities have their inherent value which is independent "independent of the usefulness of the non-human world for human purposes" (Sessions, 1995, p. 68). Mutual dependence, harmonious co-existence and recognition of all lives will only help in the betterment of environmental conditions. Such an advocacy of ecological consciousness is also witnessed in the friendship of the race of monkeys and Bharata lineage. In the Shiva Purana, it is mentioned that Hanuman attempted and overcame the invincible to save Lakshmana's life by bringing the herb of Sanjivani. Now, Hanuman is also a deity and worshipped for his infinite love of Lord Ram. The bond of love shared by Ram with Hanuman is one of the most regarded religious pictures of Indian Culture.

In the Shiva Purana, there are other didactic myths which promote justified use of resources and condemn greed. These tales preach that hunger should include basic needs and never be gluttony. Ranchor supports Gandhi's view that "the earth had enough for every one's need, but not for a few people's greed" (Prime, 2002, p. 133). It is necessary to re-examine the meaning of hunger. Hunger should never refer to insatiability. The first story is about a Brahmin's son who got killed by a cow. It happened that the father of the Brahmin's son repeatedly thrashes the calf or its mother to receive more milk. But, the Cow, unable to bear the cruelty, any longer, killed the Brahmin's son. The human-animal conflict not only projects that animals have sentiments and affection alike humans but also criticizes abuse of non-human elements because of human greed. Another story about Gurudraha and his attainment of enlightenment is narrated in the text Shiva Purana. Clinched by starvation, Gurudraha, once went to the forest in quest of food. Interestingly, the day was Shivaratri, the auspicious occasion dedicated to Lord Shiva's worship. Gurudraha climbed a Bael tree and patiently waited for prey. Three deers came that way one by one. On witnessing the animas, Gurudraha became greedier and wanted to clasp all of them, although only one was sufficient for the family. The animals seeked Gurudraha's ermission to visit their loved ones and promised to return. So, Gurudraha waited and he was blessed with enlightenment. He, no longer, felt greedy and experienced a feeling of contentment. His desire to kill the deers left him too. Through this story, the emotions and sentiments of animals are emphasized upon. Moreover, it conveys the message that true enlightenment comes in the realization of compassionate and empathetic approach towards all lives. It is important to understand that happiness comes from caring and sharing and not through exploitation. Wisdom descended and changed the personality of Gurudraha altogether. Knowledge should, thus, make people humble, sensitive and benevolent. Hence, these stories support compassion for animals and recognition of their rights and lives. Moreover, they act as critique of overexploitation, greed or cruelty. Therefore, it is rightly justified that hunger for goodness and righteousness, but not insatiability should define humanity.

Another instance of Sage Atri's wife, Anasuya clarifies that exploitation or misuse of resources should always be discouraged. Drought covered the entire area for around fifty years due to absence of rain. Sage Atri underwent tremendous penance to please the Gods for rain. Now, one day, he felt very thirsty and Anasuya, in quest of water, met Ganga. Ganga, as we already know is anthropomorphism of the mighty river. Ganga asked for Anasuya's wish and "Anasuya demanded only a Kamandal full of water" (Shiva Purana). Through the character Anasuya and her wise wish, over-consumption is criticized and judicious use is advocated. Anasuya could have asked for more water and wasted it, but she knew the value of each drop of water and wants everyone to understand as well as realize the significance of each drop of water. This tale, thus abides by the principle of the Vedas that consuming more would mean stealing from other person or species or may be, generation. So, sustainable and justified use of resources must always be emphasized.

\section{Conclusion}

This research paper has tried to analyze the potentiality of myths in infusing ecological consciousness. Indian Philosophy has always displayed a bio-centric approach, thereby, getting reflected in the mythical texts like Shiva Purana. It is an obvious sight 
that people have begun discarding theological ideologies and mythological literature as irrational and fancy stories. However, a deeper and sincere introspection would help the readers realize the wise and rational ideas conveyed through these myths. So, modernity annihilated the faith system but degradation of life, society and nature has called for rethinking and revival of spiritualism and religiousness. It is this faith and religious works that can pull back the humanity from the lures of modernity and help in tackling the rapid environmental depletion. Tony Watling quotes Palmer and Finlay's argument that "it is by telling...stories that religions are...most persuasive and positive in protecting the environment, both by reminding people of the right way of doing things and by promoting a greater sense of responsibility for natural resources" (as cited in Watling, 2009, Chapter 2). In this study, it has been explored that deification of varied elements of nature helped in protecting them and imbibing regard in humans for non-human entities. Embracing spiritualism is believed to bless one with enlightenment but that wisdom must teach everyone to conquer unquenchable hunger and act for the rejuvenation of environment, as a whole. Justice S.Vaidyanathan rightly said:

Our tradition and values, passed down to us from our ancestors, are not wrong beliefs. They are scientific, rational and logical. That is why they worshipped nature. It is not at all irrational. When nature gets the sanctity, it will not be ruined...Thus, nature was protected in those days. However, in the name of rationality, religious taboos were violated, the result of which we suffer these days. (as cited in Krishna, 2017, p. 24).

It can be concluded that biocentricism and interconnectedness with nature are the core issues contained in Indian theology and ancient Indian literature. Indian Philosophy is filled with ample knowledge to guard the splendor of nature and all the inner linkages. For further study scholars and researchers would definitely, find a handful of issues in this text and other classical Indian literature as well to investigate it from the lens of Deep Ecology, ecofeminism and others.

\section{References}

[1] Cheryll, G., \& H. F, (eds.). (1996). The Ecocriticism Reader: Landmarks in Literary Ecology. Georgia: University of Georgia Press.

[2] Des Bouvrie, S. (N.d). The definition of myth: Symbolical phenomena in ancient culture.

[3] Desai, Falguni P. (2009). Ecological Ethics in Vedic Metaphysics an Effectual Method to Indoctrinate Environmental Awareness. Journal of Environmental Research And Development, 4(2), 636-642. Retrieved from Web.

[4] Doniger, W. Purana: Hindu Literature. Britannica. Retrieved from https://www.britannica.com/topic/Purana.

[5] Ecology and Religion: An Overview. (2020). In Encyclopedia of Religion. Retrieveed from Encyclopedia.com.

[6] Garrard, G. (2012). Ecocriticism. 2nd ed. New York: Routledge.

[7] George, S (ed.). (1995), Deep Ecology for the Twenty-First Century. Boston: Shambhala Publications.

[8] Kermani, V. (2017). What modern ecology can learn from ancient Hinduism. Ecologise. In. Retrieved from Web.

[9] Krishna, N. (2017). Hinduism and Nature. Haryana: Penguin Random House India Pvt. Ltd.

[10] Longkumer, S. (2009). Panca Mahabhutas: An Ecological Readings in the Vedas and Vedanta. Kolkata: Punthi Pustak.

[11] Mark, J. (2018). Mythology. Ancient History Encyclopedia Foundation Web. Retrieved from Web.

[12] Prime, R. (2002). Vedic Ecology: Practical Wisdom for Surviving the $21^{\text {st }}$ Century. Novato: Mandala Publishing.

[13] Sharma, P. (2011). Ecocriticism and The Ramayana of Tulsidasa. USA: Lambert Academic Publishing.

[14] Shiva Purana. Trans. International Gita Society. All 18 Major Puranas. International Gita Society. Retrieved from https:// gita-society.com/wpcontent/uploads/PDF/ALL18MAJORPURANAS.IGS.html.

[15] Singh, A. (2019). Planet, Plants \& Animals: Ecological Paradigms in Buddhism. Delhi: Primus Book.

[16] Watling, T. (2009). Ecological Imaginations in the World Religions: An Ethnographic Analysis. London: Continuum International Publishing Group. 